\title{
Assessment of biochemical and technical indicators of the quality of plum fruits grown in the south of Russia
}

\author{
Tatiana Prichko, and Natalia Droficheva* \\ FSBSC North Caucasus Federal Scientific Center of Horticulture, Viticulture, Winemaking, st. 40 Let \\ Pobedy, 39, Krasnodar, Russia
}

\begin{abstract}
The results of studies 20 varieties of plum are presented. Highlighted the varieties with high quality indicators, grown in the south of Russia. The fractional composition of sugars, organic acids, aromatic substances, vitamins, polyphenols, amino acids and minerals has been studied. According to the results of the research, a prescription composition of canned food "Plum Jam" has been developed.
\end{abstract}

\section{Introduction}

Plum fruits are in demand due to their excellent organoleptic characteristics. Among the stone fruit crops, plum takes the second place after peach in the collection of fruits in the world, which is confirmed by the volume of its production - more than 10 million tons per year. The major leaders in the cultivation of this culture are the countries of Asia and Europe China considers as the world leader in the production of plums, which is - more than 5 million tons per year $[1,2,3]$.

Most of the countries producing plum fruits depend on climatic conditions and the assortment of fruits, which helps to supply products for export in different summer months.

Currently, Chile is the main exporter of plums in the world market, where a wide range of both European and Japanese varieties are grown. The fruits of the grown European varieties are mainly used for the production of prunes $[3,4,5]$.

The annual production of plum fruits in Russia is about 130 thousand tons. This culture is widespread in regions with favorable natural climatic conditions - mainly in the North Caucasus, in the Lower Volga region. Plum fruits are relatively widely represented in the gardens of the Central Federal District $[5,6]$.

The popularity of plums is associated with the good taste of the fruits and their therapeutic and prophylactic value in human nutrition. In terms of calorie content, plum fruits surpass many popular crops, second only to grapes and cherries. The average energy value of fresh fruits is about $45 \mathrm{kcal}$, juices - $70 \mathrm{kcal}$, compotes - $100 \mathrm{kcal}$, prunes - 240 kcal, jam - $560 \mathrm{kcal}$ per $100 \mathrm{~g}$ of product $[7,8]$.

\footnotetext{
* Corresponding author: drofichevanata@yandex.ru
} 
The value of plums from the point of view of fruit growing is determined by the relative early maturity, good yield, and from the point of view of processing - by great manufacturability in the production of many types of canned food $[9,10,11]$.

\section{Materials and Methods}

The objects of the study were 20 plum varieties with different ripening periods and the chemical composition of fruits grown in the south part of Russia. All laboratory studies were carried out on the equipment of the Center for Collective Use of Technological Equipment (Center for Shared Use of Technological Equipment in the following areas: genomic and post-genomic technologies; physiological, biochemical and microbiological studies; soil, agrochemical and ecotoxicological studies; food safety) according to generally accepted methods and GOSTs. In the study of the quality indicators of plum fruits, the following was determined: soluble solids - according to GOST ISO 2173-2013 with a digital refractometer PAL-3 (ATAGO); common sugars - by a photometric method on a KFK-3-01 photoelectric colorimeter in accordance with GOST 8756.13-87; fractional composition of sugars (D-glucose and D-fructose) - according to GOST R 51440-99; titratable acids by titration in the presence of phenolphthalein indicator in accordance with GOST ISO 750-2013; fractional composition of organic acids, amino acid composition, minerals - on the device "Kapel"; vitamin C - by the iodometric method with potassium iodate; vitamin P - colorimetric method modified by L.I. Vigorov with vanillin reagent; pectin substances - by the carbazole method modified by Sapozhnikova. aromatic substances - on a gas chromatograph "Crystal 2000M". Statistical processing of the results had been done using the Microsoft Office Excel program [9, 10, 11].

\section{Results and Discussion}

In the conditions of the Kuban, the ripening period of plums lasts from July to October, which ensures the workload not only of the food market, but also of fruit processing plants with raw materials. According to the size of the fruits, the assortment of plums is divided into small ones - the average weight of the fruit is up to $25 \mathrm{~g}$; medium from 26-35 g and large - over $35 \mathrm{~g}$ (table 1). According to the taste of fruits, they could be divided into four groups: dessert, table, varieties with the immediate taste and varieties with the low taste. Due to the specific combination of sugar, acid, pectin and tannins, plum fruits are widely used in the canning industry for the production of juices, jams, compotes, candied fruits, it is dried and frozen [11].

Table 1. Technical indicators of the quality of plum fruits.

\begin{tabular}{|c|c|c|c|}
\hline \multirow{2}{*}{ Variety } & \multicolumn{2}{|c|}{ Varying } & \multirow{2}{*}{$\begin{array}{l}\text { Index } \\
\text { shape }\end{array}$} \\
\hline & mass, $\mathbf{g}$ & fruit height, $\mathrm{mm}$ & \\
\hline Kabardinskaya early & $50,0-62,2$ & $43,6-44,6$ & 1,11 \\
\hline Kubanskiy karlik & $28,6-29,8$ & $38,2-39,0$ & 1,17 \\
\hline Legend & $33,0-35,0$ & $44,5-46,5$ & 1,20 \\
\hline Milena & $44,2-46,0$ & $43,00-47,0$ & 0,84 \\
\hline Stanley & $30,0-37,5$ & $47,8-48,0$ & 1,34 \\
\hline Chachakskaya early & $45,5-46,0$ & $47,0-50,0$ & 1,70 \\
\hline
\end{tabular}

The analysis of related features showed that only by choosing a variety the assortment of fruits could diversified in appearance, taste, and nutritional value.

One of the main requirements for the variety is the high quality of the fruit. The taste and nutritional properties of fruits are largely due to the chemical composition: the content of soluble solids, sugars, acids, vitamins [12, 13, 14]. Plum fruits of different varieties differ among themselves not only in technical parameters (shape, size, color, hardness), but also in biochemical characteristics (carbohydrates, vitamins, minerals, etc.). 
The harmonious taste of the fruits and their nutritional properties, which characterize their quality, were determined by the chemical composition. Plum fruits are included in the group of juicy fruit raw materials since fruits contain about $80 \%$ water, which characterizes this fruit as the low calorie contented; in addition, nutrients are in a dissolved state are easily absorbed during digestion. Natural and climatic conditions have a great influence on the content of water and dry matter in fruits. Plum fruits are characterized by a high dry matter content - from 12.0 (Black Star) to 21.0\% (Ballad, Autumn souvenir) (Fig. 1).

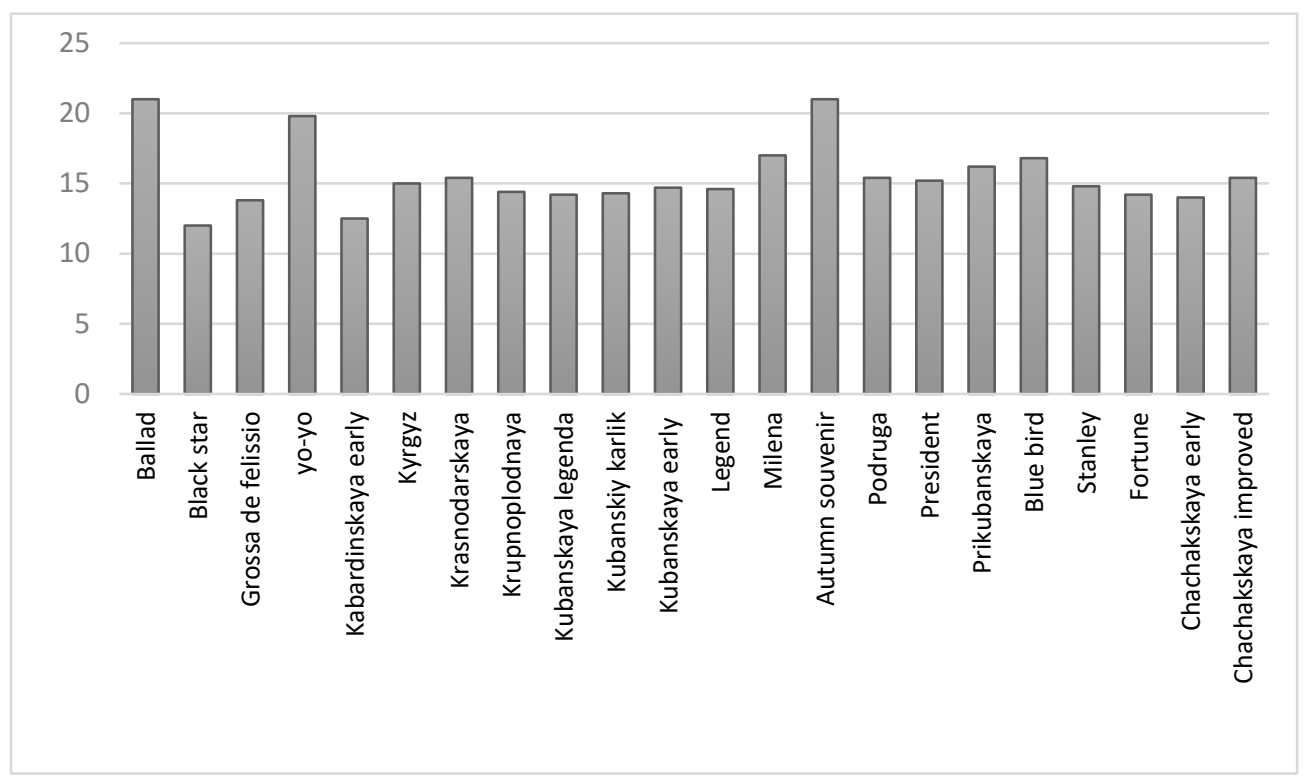

Fig. 1. The content of dry matter in plum fruits.

The main part of solible solids of plum fruits are carbohydrates, represented by monosaccharides (mainly glucose and fructose) and polysaccharides of the first (mainly sucrose) and second orders (starch, cellulose, hemilcellulose, pectin substances).

According to the average species data, in plum fruits, more than half of the amount of sugars is represented by sucrose, in smaller amounts glucose and fructose are contained. Variations in the carbohydrate composition of plum fruits, taking into account varietal characteristics, are shown in Figure 2.

Fructose, or "fruit sugar", is found in almost all fruits and is the sweetest of all sugars. The threshold for the sensation of sweetness, i.e. the minimum concentration at which a sweet taste is felt is $0.25 \%$, for sucrose - $0.38 \%$, for glucose $-0.55 \%$. Fructose is recommended as a source of easily digestible carbohydrates for patients with diabetes mellitus, since, unlike glucose, when it enters the bloodstream, it is more intensively involved in metabolic processes [14, 15, 16].

Glucose is the main source of energy and in its pure form is absorbed by the body better than other sugars. Glucose can be found both in free form and in bound form as part of starch, fiber and other complex carbohydrates. This sugar is an essential component of blood, and is also a part of lymph and cerebrospinal fluid [17, 18, 20]. 


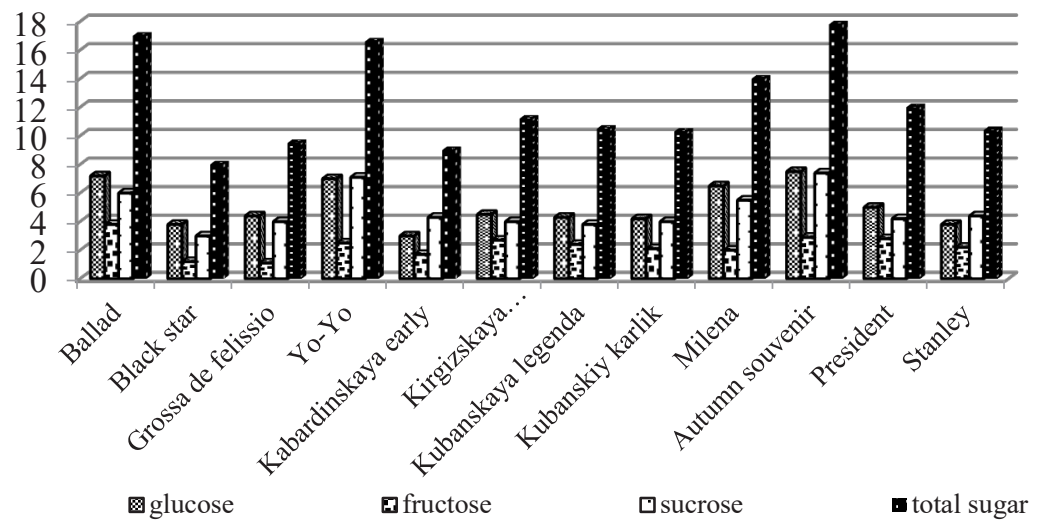

Fig. 2. Fractional composition of sugars in plum fruits.

There is a wide range of variation in the content of organic acids in plum fruits $0.50-1.76 \%$. The varieties Black Star, Kabardinskaya Early and Grossa de Felissio stand out for their high acidity. Organic acids are mainly represented by malic, citric and succinic acids (table 2).

Table 2. Fractional composition of organic acids of plum fruits.

\begin{tabular}{|c|c|c|c|}
\hline \multirow{2}{*}{ Variety } & \multicolumn{3}{|c|}{ Acid content, \% } \\
\cline { 2 - 4 } & apple & lemon & amber \\
\hline Kabardianskaya early & 1,52 & 0,03 & 0,02 \\
\hline Kubanskiy karlik & 0,51 & 0,003 & 0 \\
\hline Black star & 1,71 & 0,014 & 0,021 \\
\hline Kubanskaya legenda & 0,49 & 0,003 & 0 \\
\hline Chachakskaya improved & 0,53 & 0,004 & 0 \\
\hline Grossa de felissio & 1,17 & 0,02 & 0,01 \\
\hline
\end{tabular}

The sourest taste is the Chinese plum Black Star, which contains the maximum amount of acids $-1.76 \%$ and the lowest sugar-acid index (SAI) - 4.0 p.u.

Since vitamins practically not synthesized in the human body it is important to consume fruit products daily, which helps in the regulation of many vital processes. Plum fruits enrich the human body with vitamins $\mathrm{C}$ and $\mathrm{P}$ polyphenolic substances.

Plum fruits contain a small amount of vitamin C - from $3.1 \mathrm{mg} / 100 \mathrm{~g}$ (Yo-yo, Milena) to $6.4 \mathrm{mg} / 100 \mathrm{~g}$ (Kuban dwarf, President), but differ in a significant content of vitamin P, ranging from $20.0 \mathrm{mg} / 100 \mathrm{~g}$ (Yo-yo) to $131.8 \mathrm{mg} / 100 \mathrm{~g}$ (Black Star) (table 3).

Table 3. Vitamin content in plum fruits.

\begin{tabular}{|c|c|c|c|c|}
\hline № & Plum variety & $\begin{array}{c}\text { Vitamin C, } \\
\mathbf{m g} / \mathbf{1 0 0 g}\end{array}$ & $\begin{array}{c}\text { Vitamin P, } \\
\mathbf{m g} / \mathbf{1 0 0 g}\end{array}$ & $\begin{array}{c}\text { Anthocyanins, } \\
\mathbf{m g} / \mathbf{1 0 0 g}\end{array}$ \\
\hline 1 & Ballad & 4,2 & 83,6 & 97,6 \\
\hline 2 & Black star & 4,6 & 131,8 & 73,2 \\
\hline 3 & Grossa de felissio & 5,3 & 86,0 & 40,3 \\
\hline 4 & Yo-yo & 3,1 & 20,0 & 58,1 \\
\hline 5 & Kabardianskaya early & 5,1 & 80,3 & 54,6 \\
\hline 6 & Kyrgyz excellent & 4,7 & 110,5 & 23,7 \\
\hline 7 & Krasnodarskaya & 5,7 & 85,2 & - \\
\hline 8 & Kubanskaya legenda & 4,9 & 106,7 & 21,4 \\
\hline 9 & Kubanskiy karlik & 6,4 & 132,9 & 53,2 \\
\hline 10 & Kubanskaya early & 5,0 & 94,2 & 48,6 \\
\hline
\end{tabular}




\begin{tabular}{|c|c|c|c|c|}
\hline 11 & Legend & 5,4 & 99,1 & 26,2 \\
\hline 12 & Milena & 3,1 & 98,7 & 40,7 \\
\hline 13 & Autumn souvenir & 5,2 & 38,8 & 40,6 \\
\hline 14 & President & 6,3 & 97,8 & - \\
\hline 15 & Prikubanskaya & 5,9 & 92,5 & 44,4 \\
\hline 16 & Blue bird & 3,4 & 110,6 & 74,3 \\
\hline 17 & Stanley & 5,8 & 81,8 & 69,6 \\
\hline 18 & Fortune & 4,4 & 106,2 & 53,2 \\
\hline 19 & Chachakskaya early & 5,3 & 41,8 & 106,4 \\
\hline 20 & Chachak improved & 5,5 & 87,7 & 97,4 \\
\hline
\end{tabular}

Among the phenolic compounds, a high content of leukoanthocyanins was also noted up to $180.0 \mathrm{mg} / 100 \mathrm{~g}$ in fruits of the variety: Black star, Kuban dwarf, Blue bird, Fortuna, which also accumulates the maximum amount of total polyphenols. In the process of ripening dark-colored plum varieties, the content of phenolic compounds increases significantly, reaching a maximum at the stage of full ripeness of the fruit.

Pectin is found in all parts of plants, being part of cell walls and intercellular formations. It is classified as protopectin and pectin. Protopectin, insoluble in water, turns into soluble pectin during fruit ripening, which causes tissue softening. The keeping quality of fruits largely depends on the rate of transition of protopectin into soluble pectin $[5,19$, $21,22]$.

In the production of marmalades, jellies, jams and other confectionery products, fruits are widely used that accumulate a sufficient amount of pectin substances, because they have gelling properties.

The content of pectin substances is inferior in this indicator to many fruit crops, they contain no more than $0.5 \%$ of pectin substances and there is no significant difference in the amount of pectin substances (Figure 3) [5, 11].

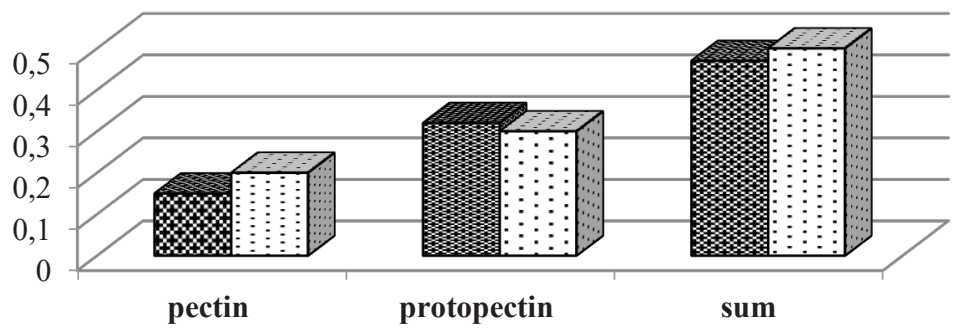

国 Kabardianskaya early $\square$ Stanley

Fig. 3. Content of pectin substances in plum fruits, $\%$.

Along with vitamins, amino acids are an important nutritional factor, which determines the taste, nutritional and preventive value of plum fruits (table 4).

Table 4. Amino acid composition of plum fruits, $\mathrm{mg} / 100 \mathrm{~g}$.

\begin{tabular}{|c|c|c|c|c|}
\hline \multirow{2}{*}{$\begin{array}{c}\text { Amino acid } \\
\text { name }\end{array}$} & $\begin{array}{c}\text { Kubanskiy } \\
\text { karlik }\end{array}$ & $\begin{array}{c}\text { Chachakskaya } \\
\text { improved }\end{array}$ & $\begin{array}{c}\text { Kubanskaya } \\
\text { legenda }\end{array}$ & Grosse de filitsio \\
\cline { 2 - 5 } & \multicolumn{5}{|c|}{ Irreplaceable } \\
\hline Valine & 1,55 & 9,16 & 19,5 & 89,7 \\
\hline Leucine & 3,46 & & 8,0 & 7,15 \\
\hline
\end{tabular}




\begin{tabular}{|c|c|c|c|c|}
\hline Methionine & 1,5 & 5,55 & & 1,38 \\
\hline Threonine & 5,15 & 9,18 & 0,59 & 0,37 \\
\hline Phenylalanine & 0,08 & 0,3 & 0,59 & 22,7 \\
\hline \multicolumn{5}{|l|}{ Replaceable } \\
\hline Alanin & 35,4 & 0,48 & 1,23 & 2,77 \\
\hline Arginine & 12,4 & 0,62 & 4,4 & 4,0 \\
\hline Glycine & 1,88 & 0,3 & 3,04 & 296 \\
\hline Serine & 31,2 & 1,2 & 0 & 0,38 \\
\hline Proline & 9,7 & 61,4 & 26,0 & 430,7 \\
\hline Tyrosine & 0 & 0,14 & 3,1 & 64,9 \\
\hline TOTAL & 102,3 & 88,4 & &
\end{tabular}

The qualitative composition of amino acids is represented by 5 essential and 6 nonessential amino acids. It should be noted the high total content of amino acids in the fruits of the Chinese plum Black Star, the level of which is 4-6 times higher than that of the studied varieties of domestic plum: Kubanskiy karlik, Chachakskaya improved and Kubanskaya legenda.

The value of the plum fruit is enhanced by the presence of aromatic substances that promote better absorption of food. In total, up to 27 components have been identified that determine the aroma of fruits, more than half are aldehydes and acids.

The composition of aromatic substances in the fruits of the Kubanskaya legenda variety was investigated, which showed that the plum contains the maximum amount of aliphatic acids (total $24.8 \mathrm{mg} / 100 \mathrm{~g}$ ) (Table 5).

Table 5. Fractional composition of aromatic substances in plum fruits, variety Kuban legend.

\begin{tabular}{|c|c|c|}
\hline Components & Total content, mg / 100g & Name of components \\
\hline ldehydes - 1 & 0,93 & Furfural $(0.93)$ \\
\hline Ketones - 1 & 3,34 & Diacetyl (3.34) \\
\hline Ketone - aldehydes - 1 & 0,04 & Acetoin $(0.04)$ \\
\hline Polyhydric alcohols -2 & 10,65 & 2.3 butylene glycol $(0.15)$ \\
\hline \multirow[t]{2}{*}{$\begin{array}{l}\text { Aromatic and aliphatic } \\
\text { alcohols - } 5\end{array}$} & 4,42 & 1.2 propylene glycol (10.5) \\
\hline & 9,57 & $\begin{array}{c}2 \text { - propanol }(0.36), \text { methanol } \\
\text { (3.6), propanol }(0.05), 1 \text {-hexanol } \\
(0.19) \text {, isoamyl }(0.17), 1 \text { - butanol } \\
(0.05) ;\end{array}$ \\
\hline Esters - 8 & 24,8 & $\begin{array}{l}\text { Ethyl formate }(0.31) \text {, methyl } \\
\text { acetate }(6.33) \text {, ethyl acetate }(0.06) \text {, } \\
\text { ethyl butyrate }(0.18) \text {, ethyl } \\
\text { caprylate }(0.06) \text {, ethyl lactate } \\
\text { (1.4), ethyl caprate }(0.96) \text {; ethyl } \\
\text { acetal }(0.27)\end{array}$ \\
\hline Total components- 22 & 53,75 & \\
\hline
\end{tabular}

Among acids, acetic acid stands out, among esters - methyl acetate - (methyl ester of acetic acid, $\mathrm{CH} 3 \mathrm{COOCH} 3$, which has a fruity odor). In the processing industry, it is used as a flavoring agent for foodstuffs.

For the development of new types of functional foodstuffs, correcting the macro - and microelement status of human nutrition, the mineral plum was investigated: Stanley and Kabardinskaya early. A study of macronutrients showed that plum fruits contain up to $165.9 \mathrm{mg} / 100$ $\mathrm{g}$ of potassium, up to $12.7 \mathrm{mg} / 100 \mathrm{~g}$ of calcium, up to $19.3 \mathrm{mg} / 100 \mathrm{~g}$ of magnesium (table 6). 
Table 6. Content of macronutrients in plum fruits.

\begin{tabular}{|c|c|c|c|c|}
\hline \multirow{2}{*}{ Variety } & \multicolumn{4}{|c|}{ Content, mg / 100 g } \\
\cline { 2 - 5 } & potassium & sodium & calcium & magnesium \\
\hline Kabardianskaya early & 91,2 & 18,4 & 12,4 & 6,2 \\
\hline Stanley & 41,4 & 8,1 & 12,7 & 5,4 \\
\hline Fortune & 165,9 & 30,0 & 11,1 & 12,3 \\
\hline $\begin{array}{c}\text { Kirgizskaya } \\
\text { prevoskhodnaya }\end{array}$ & 95,9 & 37,6 & 11,1 & 19,3 \\
\hline
\end{tabular}

All varieties contain a significant amount of calcium, which affects blood coagulation and water exchange in the human body, normalizes the metabolism of carbohydrates, sodium chloride, regulates muscle contraction and hormone secretion, reduces the level of vascular wall permeability, and has an anti-inflammatory effect. Daily intake of calcium for an adult $-0.8 \mathrm{~g}$; therefore, the use of even $0.5 \mathrm{~kg}$ of plums helps to ensure the daily rate of its consumption. In fruits, calcium, together with pectin, affects the structure of fruit tissues, making it more durable and protecting it from cooking when sterilizing canned food [11, $17,20]$.

Based on the obtained data, a prescription composition of canned food "Plum jam" was developed (table 7).

Table 7. Biochemical indicators of the quality of canned food "Plum Jam".

\begin{tabular}{|l|c|c|c|c|c|}
\hline \multirow{2}{*}{$\begin{array}{c}\text { Component } \\
\text { name }\end{array}$} & \multicolumn{4}{|c|}{ Content, mg / 100 g } & \multirow{2}{*}{ Pectin,\% } \\
\cline { 2 - 5 } puree, & vitamin P & vitamin PP & amino acids & polyphenols & \\
\hline $\begin{array}{l}\text { Plum } \begin{array}{c}\text { pariety Stenley } \\
\text { varnar }\end{array} \\
98,9\end{array}$ & 0,2 & 115,2 & 325,5 & 1,0 \\
\hline Granulated sugar & 0 & 0 & 0 & 0 & 0 \\
\hline Finished product & 73,8 & 0,15 & 185,0 & 349,5 & 1,0 \\
\hline
\end{tabular}

The conducted tasting assessment of a functional food product - sterilized fruit jam "Plum-grapes" - confirmed a higher overall assessment compared to the control (Figure 4).

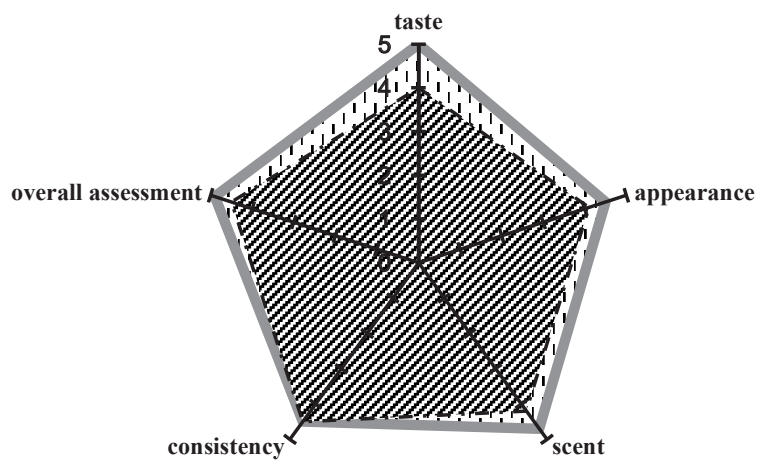

- finished product

z(jam in accordance with GOST 32099-2013)

Fig. 4. Tasting evaluation of canned food "Plum Jam".

The available scientific and methodological method for obtaining functional products makes it possible to develop food of a higher level, taking into account the requirements of modern dietetics and medicine. 


\section{Conclusion}

Based on the performed comprehensive studies of the quality indicators of plum fruits, taking into account the varietal characteristics, allow us to recommend the selected varieties for industrial planting and further use in the processing industry as a high-vitamin raw material.

\section{References}

1. G.V. Eremina, SKZNIISiV, 3, 4-50 (2011)

2. E.N. Sedova and T.P. Ogoltsova, Program and methodology for the study of varieties of fruit, berry and nut crops, 606 (Eagle, 1999)

3. Program and methodology for selection of fruit, berry and nut crops, 503 (Eagle, 1995)

4. Ezinne O. Igwe, Karen E. Charlton, Phytother Res. (2016) doi:10.1002/ptr.5581

5. O.Y. Dubrovskaya, Biochemical composition of plum varieties and forms and selection of the best genotypes for breeding use and processing, 130 (Michurinsk, 2015)

6. N.V. Makarova, N.B. Eremeeva, Antioxidant activity of plum extracts In collection: Modern food technologies. 2nd International Scientific and Practical Conference, 9799 (2015)

7. F.N. Meretukova, New technologies, 1, 42-45 (2012)

8. U. Nazar, Raza Amin, A multi-target therapeutic potential of Prunus domestica gum stabilized nanoparticles exhibited prospective anticancer, antibacterial, ureaseinhibition, anti-inflammatory and analgesic properties (2017) doi: 10.1186/s12906017-1791-3

9. C. Nunes, A.E. Ratob, A.S. Barrosa, J.A. Saraivaa, M.A. Coimbraa, Food Chemistry, 112, 570-57 (2009)

10. V.P. Popova, N.N. Sergeeva, O.V. Yaroshenko, A.P. Kuznetsova, Potravinarstvo Slovak Journal of Food Sciences. 14, 1075-1087 (2020) https://doi.org/10.5219/1469

11. T.G. Prichko, Biochemical and technological foundations of intensification of production, storage and processing of fruits andberries, 482 (Krasnodar, 2002)

12. F. Cuque, A. Motta, I. Tutida, L. May-De Mio, Revista Brasileira de Fruticultura, 3 (3), 328-336 (2011) https://www.doi.org/10.1590/S0100- 29452011000500041

13. G.Y. Upadyshev, M.T. Upadyshev, Effectiveness of biological products at cultivation of plums. Prospects for the use of new forms of fertilizers, plant protection agents and growth regulators in agricultural technologies of agricultural crops, 285-289 (Moscow, Russia, 2014) ISBN: 978-5-9238-0174-3

14. G.Y. Upadysheva, Features of growth and production process in plum (Prunus domestica L.) during the formation of small-sized crowns. Methods and technologies in plant breeding and crop production, 487-490 (Kirov, Russia, 2015)

15. T.G. Prichko, Biochemical and technological bases of intensification of production, storage and processing of fruits and berries, 54 (FSBSI SKFNTSSVV, Krasnodar, 2002)

16. T.G. Prichko, Fruit growing: scientific 21, 365-373 (2009)

17. T.G. Prichko, N.V. Droficheva, Use of fruit and berry raw materials for canned products, taking into account varietal characteristics, 24 (Guidelines, 2019) (in Russian) 
18. P.E. Bogdanov, Biological features and economic value of plum varieties and forms for production and selection: abstract of the PhD thesis, 23 (Michurinsk, Russia, 2003)

19. M.T. Upadyshev, The role of phenolic compounds in the life processes of garden plants, 319 (VSTISP, 2008)

20. T.G. Prichko, N.V. Droficheva, Polycomponent products of gerodietic purpose from fruit and berry raw materials, Innovative food technologies in the field of storage and processing of agricultural raw materials: Fundamental and applied aspects: materials of the $V$ Int. scientific-practical conf., 14, 178-181 (FGBNU KNIIHP, Krasnodar, 2015)

21. H.P. Sharma, H. Patel, S. Sugandha, Crit Rev. Food Sci Nutr. V. 57 (6), 1215-1227 (2017)

22. A.V. Istomin, T.L. Pilat, Hygienic aspects of the use of pectin and pectin substances in therapeutic and prophylactic nutrition: a guide for doctors I89, 44 (M., 2009) ISBN 978-5-9901714-1-1 